\title{
Artistic Achievements of Artistically Gifted Children: Artefacts of Artistic Development from Early Childhood to Artistic Maturity
}

\author{
Nikolay Marinov Dinev \\ National Academy of Art - Sofia, BULGARIA
}

Received 25 April 2019 • Revised 2 July 2019 • Accepted 12 July 2019

\section{Abstract}

\begin{abstract}
Children's creativity is a first touch to the fine arts for many people. Artistically gifted children have almost undoubtedly interesting development as adults as well. It is a fact many of our wellknown artists keep their children's drawings and paintings. Plenty of artists draw and develop from a very early age and offer a long, interesting and ambiguous artistic path. One of the many and not the only examples to confirm the thesis are the world-famous painters Pablo Picasso, Joan Miro, Henri de Toulouse-Lautrec, Paul Klee ... A lot of artists continue to develop their interest in Childhood as a unique emotional territory, in the childlike view of the world, in the remarkable spontaneity of children's stylistics...
\end{abstract}

Keywords: gifted children, childhood, drawings, children stylistics.

Children's creativity is a first touch to the fine arts for many people. The first children's drawings also carry the first promises of future development. Almost every artist keeps something from his childhood, which he attaches to his experience. A big part of the established artists draws from their childhood, there are a lot of drawings preserved from their childhood years, and many of them represent considerable achievements. These drawings are a subject of special interest not only as a first sign of talent, of creative skills, of artistic individuality, but also as a selection of themes, as an emotional sense of the world... Many of their children's interests, choice of images for recreating, colors, have their own continuation in their artistic way as adults as well. A number of painters constantly turn back to childhood, as to a source of a forgotten bright beginning, of unique shapes, lines, spots, of spontaneity and purity

Artistically gifted children have almost undoubtedly interesting development as adults as well. They do not always become artists, but they always bring that creative childish flame. They continue to be creators even in other directions. Being an artist in the childhood determines the way of life of the adult, gives positive direction and multiplies their interests, projects and achievements.

It is a fact many of our well-known artists keep their children's drawings and paintings. Plenty of artists draw and develop from a very early age and offer a long, interesting and ambiguous artistic path. One of the many and not the only examples to confirm the thesis are the

(C) Authors. Terms and conditions of Creative Commons Attribution 4.0 International (CC BY 4.0) apply. Correspondence: Nikolay Marinov Dinev, National Academy of Art - Sofia, BULGARIA. E-mail: nmar@abv.bg. 
world-famous painters Pablo Picasso ${ }^{1}$, Joan Miro $^{2}$, Henri de Toulouse-Lautrec ${ }^{3}$, Paul Klee ${ }^{4}$. A lot of artists continue to develop their interest in childhood as a unique emotional territory, in the childlike view of the world, in the remarkable spontaneity of children's stylistics ... A large number of artists collect children's drawings, draw together with their children, participate in projects related to childhood. But all directly or indirectly associate their creativity with the themes, colors, feelings of the distant but not totally forgotten childhood.

Pablo Picasso is undoubtedly one of the greatest artists of our time. He had been painting from early childhood and his early paintings, preserved to this day, are proof of bright artistic talent... Certain themes and objects are of constant interest for him... People, bulls, pigeons, animals, their characteristic expression can be traced back to Picasso's childhood years, through the development of different periods and styles to his ripe old age.
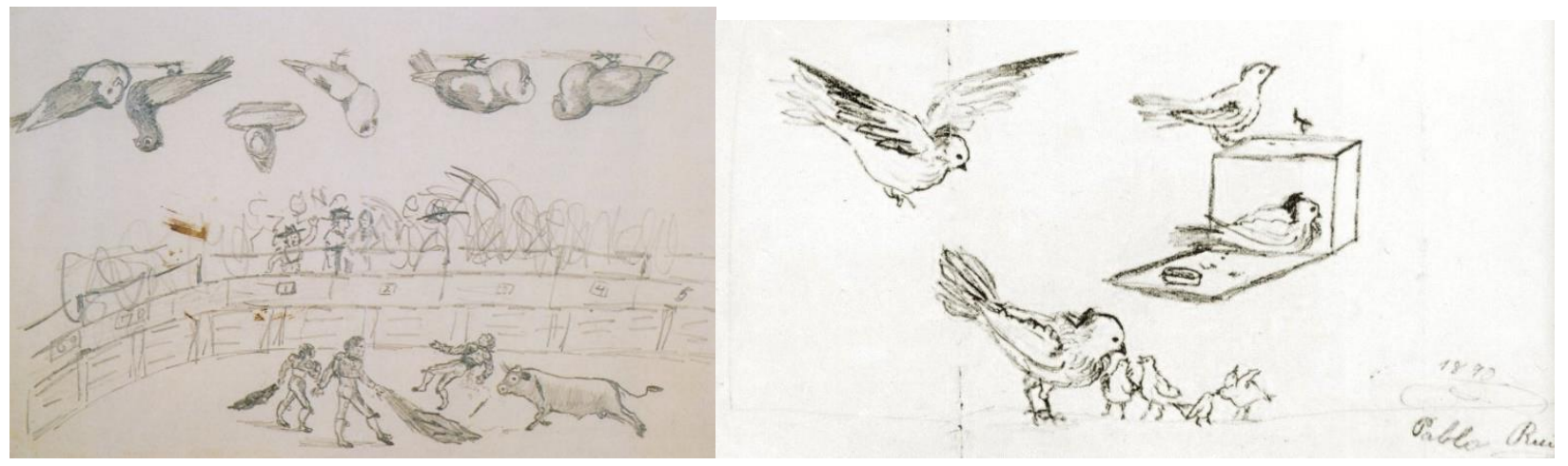

Exposure 1. Pablo Picasso - 1890 (9 years old), "Bullfight and Pigeons" and "Pigeons"
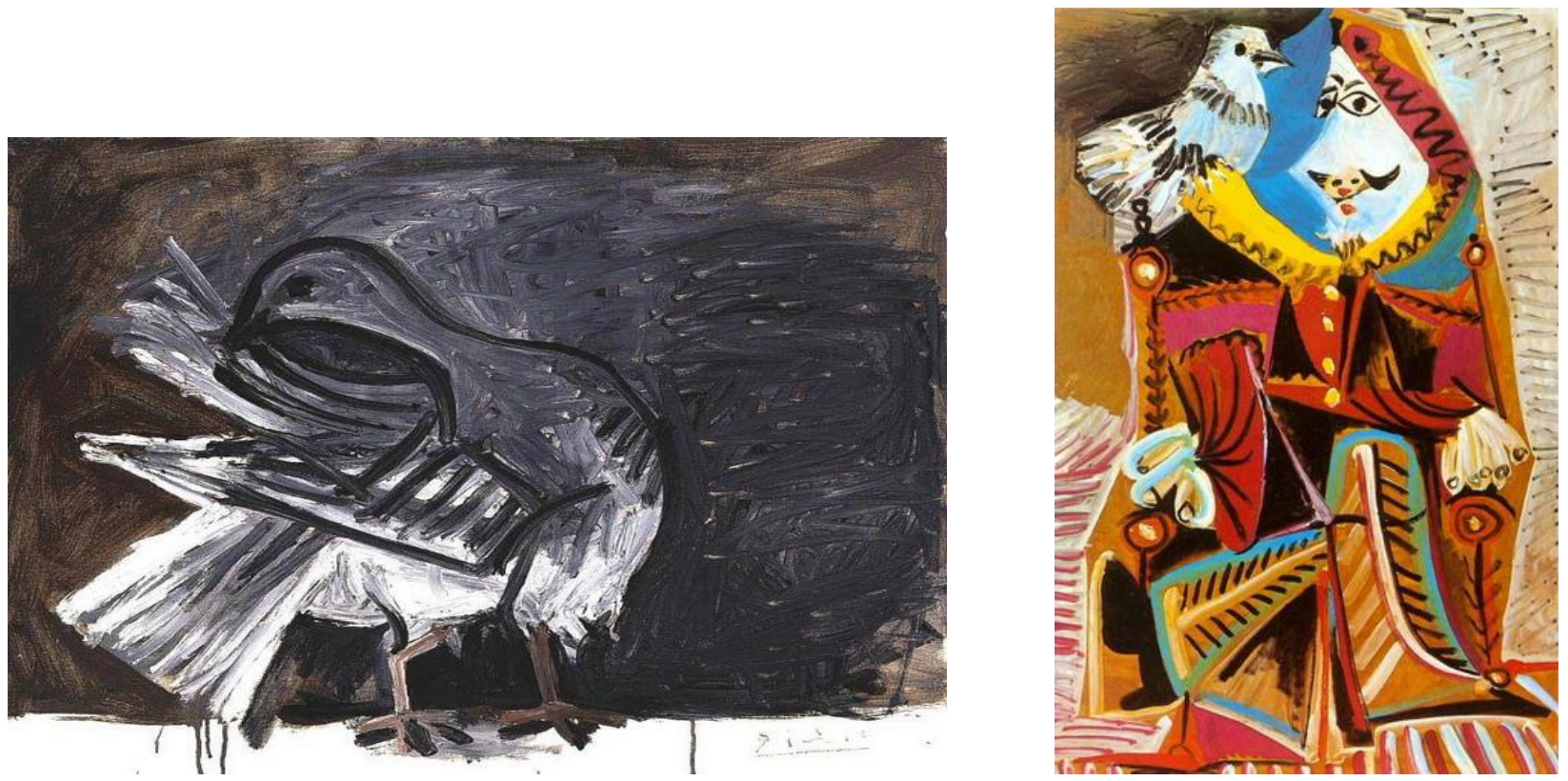

Exposure 2.Pablo Picasso - “Pigeon”, 1960, and "Musketeer”, 1969

${ }^{1}$ https://www.pablo-ruiz-picasso.net/.

2 https://www.wikiart.org/en/joan-miro.

3 https://www.toulouse-lautrec-foundation.org/.

4 https://www.paulklee.net/. 
One of the emblematic artists of the $20^{\text {th }}$ century is Joan Miro. Fortunately, we can see his children's paintings when the artist is only 9 years old ... "Flower Pot with Flowers" and "Umbrella" show already created style, precision and pedanticity to nature. The spontaneity of the child's painting, the bold shaping of the image, the bright color, the attention to detail and the capture of the characteristic emotion is what the artist keeps in himself from his early years, from his first paintings.

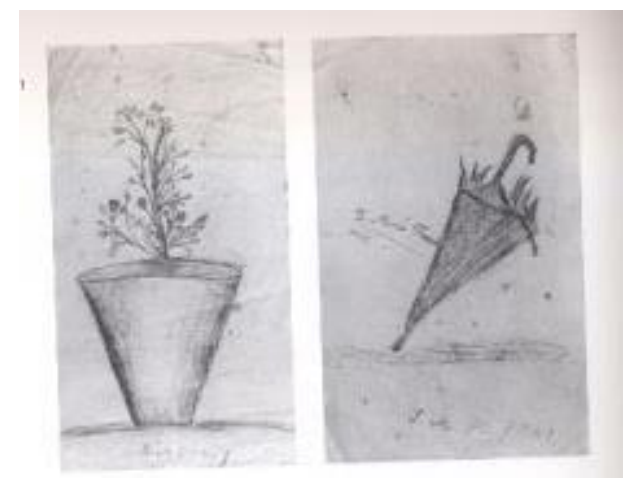

Exposure 3. Joan Miro - 1901 (9 years old), "Flower Pot with Flowers" and "Umbrella"
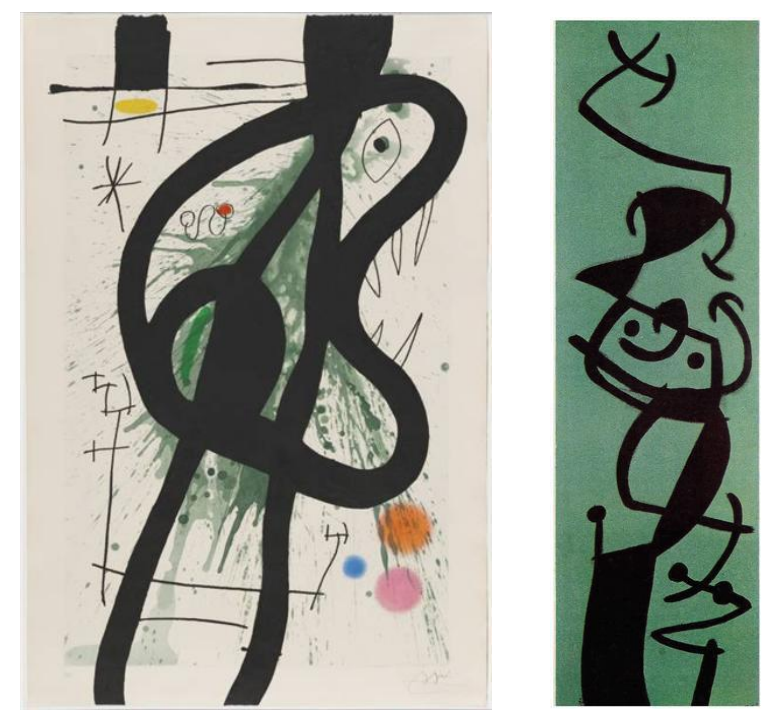

Exposure 4. Joan Miro - "The Great Carnivore", 1969, and "Woman and bird”, 1967

One of the brilliant, remarkable artists, with a style which is difficult to be classified and attributed to from the late 19th century and the first years of the 20th century, is Henri de Toulouse-Lautrec (1864-1901). In his short creative path (the artist died only at the age of 37) Toulouse-Lautrec created many works of exquisiteness, light, precision in detail and movement. Horse racing is one of the topics in the artist's works of childhood. 
N. M. Dinev - Artistic Achievements of Artistically Gifted Children: Artefacts of...

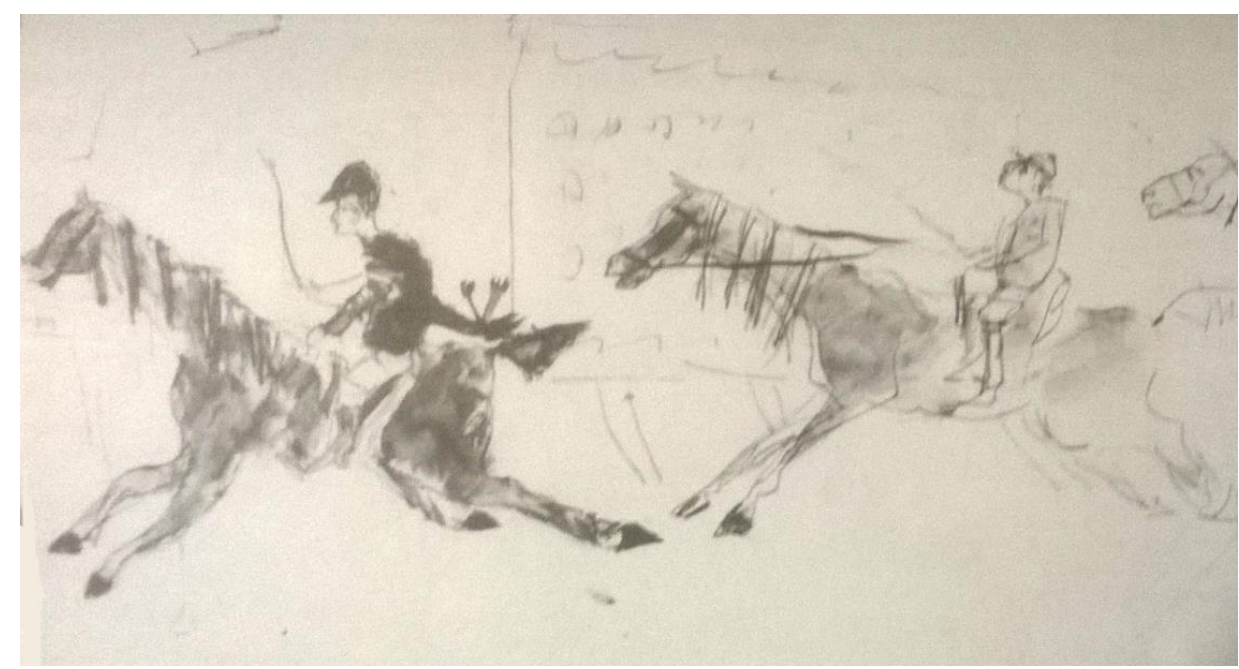

Exposure 5. Toulouse-Lautrec (1864-1901) - “The Race”, 1874 (10 years old)
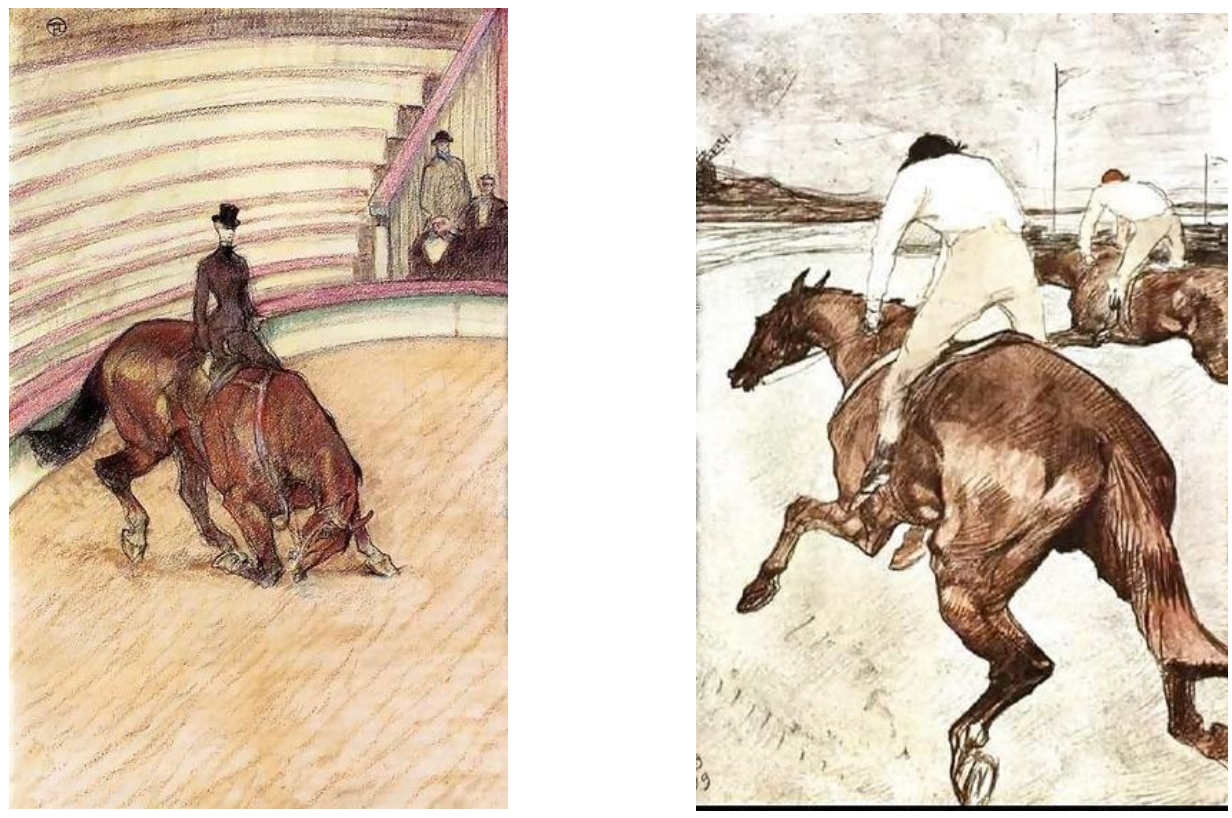

Exposure 6. Toulouse-Lautrec - "The circus" and "The Jockey"

One of the emblematic painters of the twentieth century is Paul Klee ... Children's stylistics, childhood as a starting point, are leading in his work ... Fortunately, Paul Klee has preserved his children's paintings, "The Woman with Parasols" (1883-85) is one of the especially successful ones... 

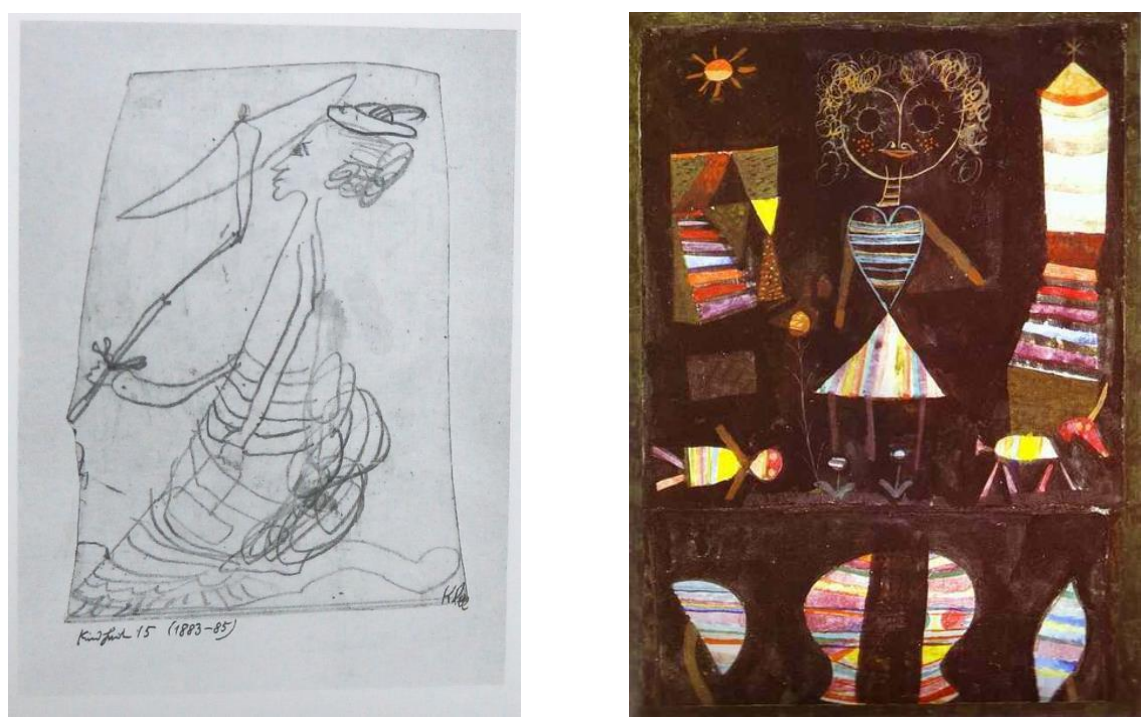

Exposure 7. Paul Klee (1879-1940) - "The Woman with Parasols" (1883-85, 4-6 years old) and "Puppet theatre" in 1923

Many children and their paintings are subject to professional research. Their emotional power and artistic independence are not unnoticed. An example of this is Eitan ... His early paintings of vehicles, later urban landscapes, as athletic figures, are the basis of the article, a study of the power of child creativity of the American psychologist Claire Golomb5 - "Eitan: The artistic development of a child prodigy" . As a teenager, Eitan redirects his interests to music and sports, helping in his spare time in his father's architecture company. The author's observations are a valuable confirmation of the basic directions of the early appearance of bright artistic talent, emotional and personal growth through art.

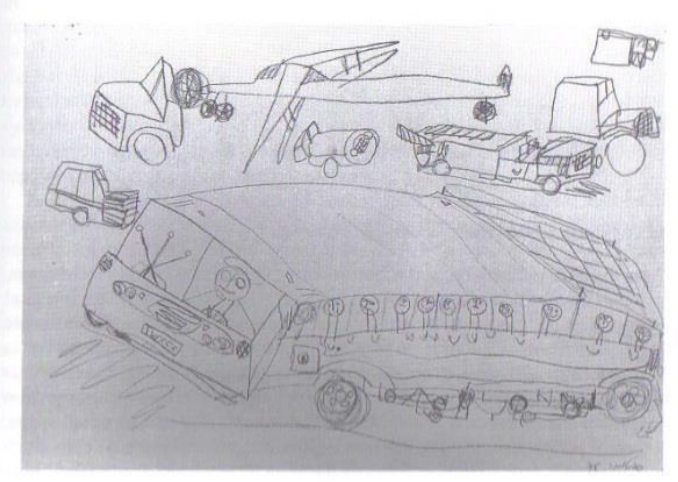

FIC 6.7. Bus in isometric projection (age 3.8).

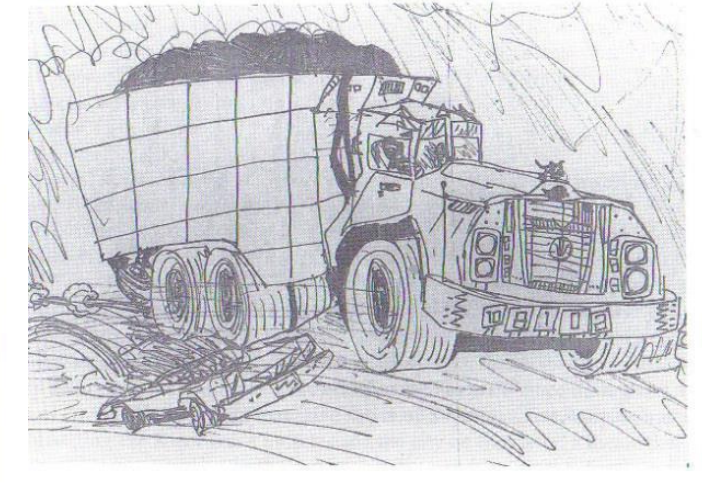

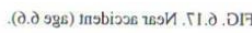

Exposure 8. Eitan - 4 years old and Eitan -7 years old

5 https://srcd.org/sites/default/files/documents/golomb_claire_cv.pdf.

${ }^{6}$ Golomb, Claire, Eitan: Artistic Development of Child Prodigy, in The Development of Artistically Gifted Children (selected case studies, edited by Claire Golomb), Lawrence Erlbaum Associaters. Publishers, Hillsdale, New Jersey, 1995. 


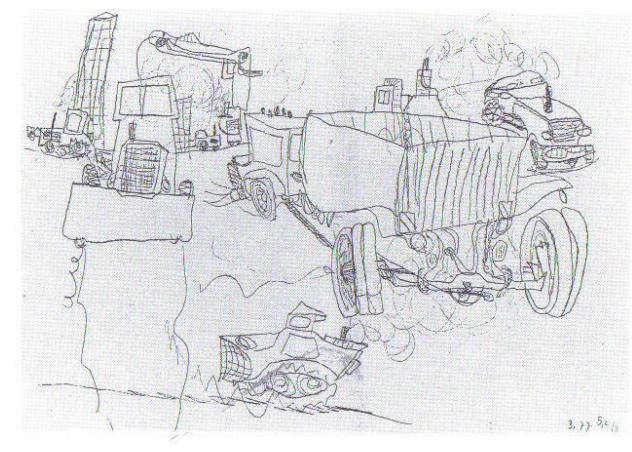

FIG. 6.15. Construction scene (age 5.2).

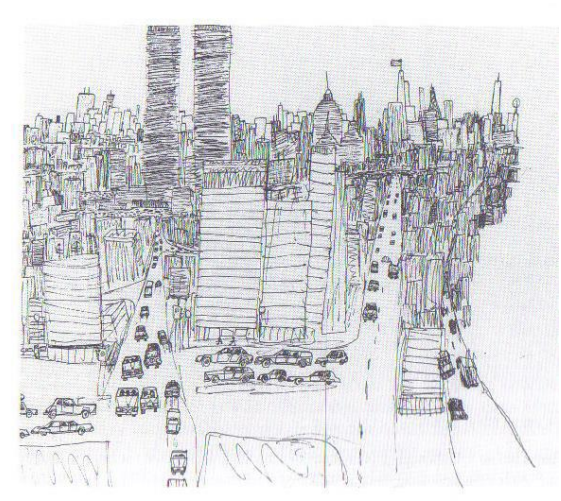

FIG, 6.19. New York City (age 7.10)

Exposure 9. Eitan - 5 years old, and Eitan -8 years old

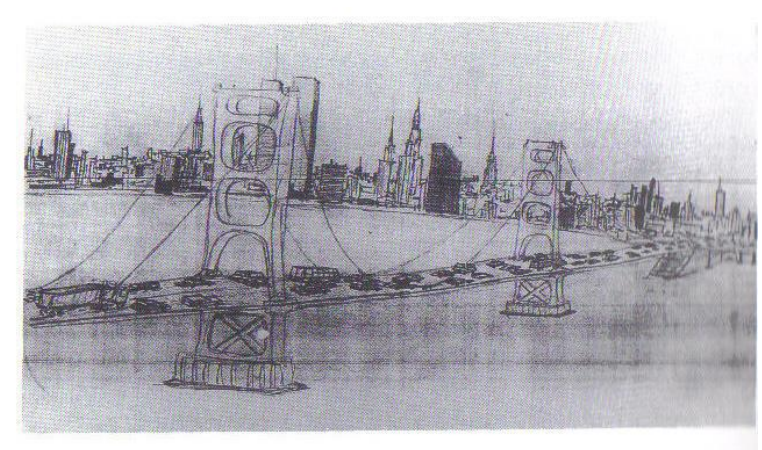

FIG. 6.20. Cityscape (age 10).

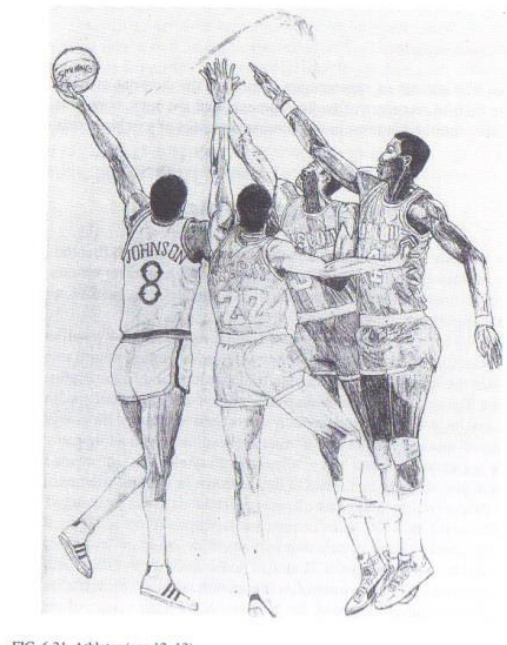

FIG. 621. Athletes (age 12-13)

Exposure 10. Eitan - 10 years old, and Eitan - 13 years old

Joel Rivers' paintings are interesting7. Constance Milbrath ${ }^{8}$, the psychologist at the University of California at San Francisco writes about him... In her article "General Motifs in the Creativity of Gifted Children - Artists"9 she follows the development of Joel's paintings from his earliest childhood to his 24 years of age (her last interview is in the winter of 1994, when Joel was 24 years old). Joel has been painting since he was 2 years old without using patterns from which to re-paint ... At the age of 3 he already paints recognizable images ... At the age of 4 he had an accident, he falls down and while recovering his mother shows different books to him ... The most interesting to him are the books about dinosaurs, especially albums for adults.... This also determines the direction of his paintings in the following years ... dinosaurs, prehistoric animals and nature with a particularly marked sense of detail ... Over the years, the paintings become more perfect, the details more accurate ... Joel does not interrupt painting, today he is an artist, with interest in visual arts, with interesting comics and animated films ... (http://joelrivers.com/).

\footnotetext{
7 http://www.joelrivers.com/.

8 http://earlylearning.ubc.ca/people/Connie_Milbrath/.

9 Milbrath, Constance, Germinal Motifs in the Work of a Gifted Artist, in The Development of Artistically Gifted Children (selected case studies, edited by Claire Golomb), Lawrence Erlbaum Associates. Publishers, Hillsdale, New Jersey, 1995, 107-132.
} 

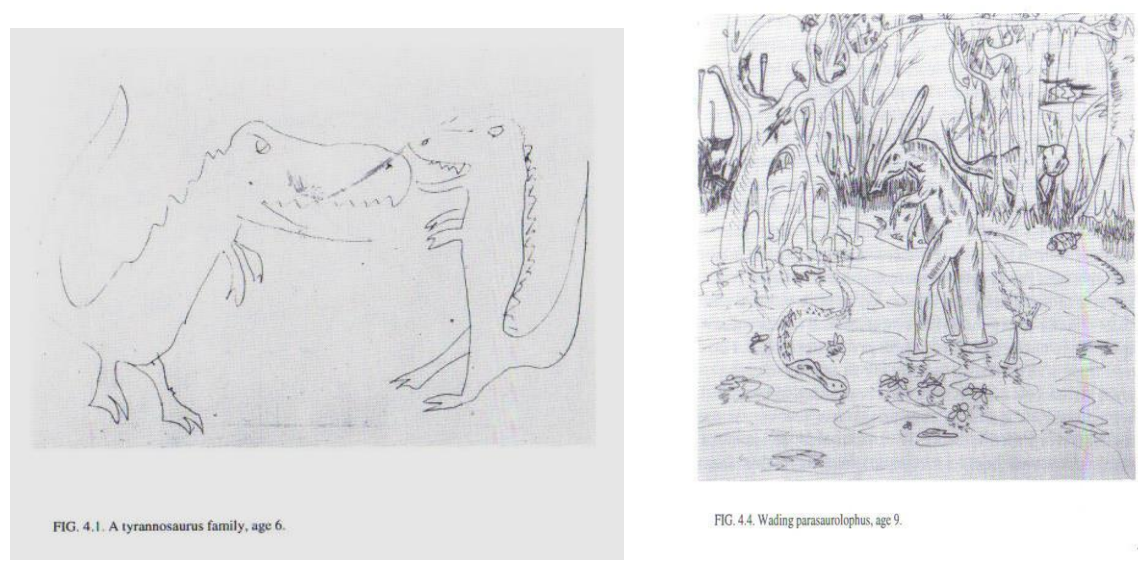

FIC.4.4. Wading parasaurolophus, age?

Exposure 11. Joel at the age of 6 and Joel at the age of 9
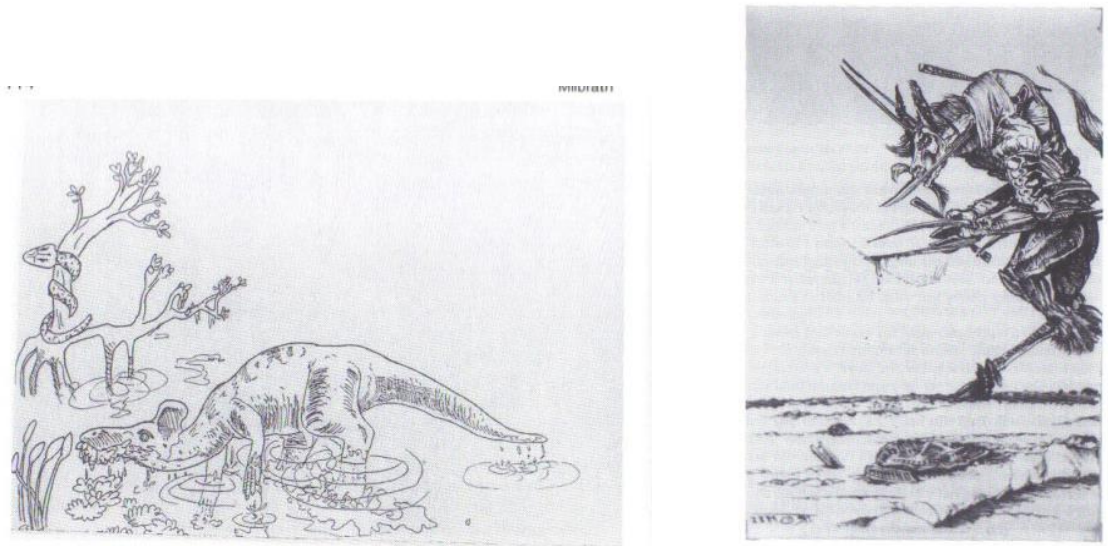

FIG. 4.5. Lambeosaurus, age 12.

Exposure 12. Joel - 12 years old and Joel - 18 years old
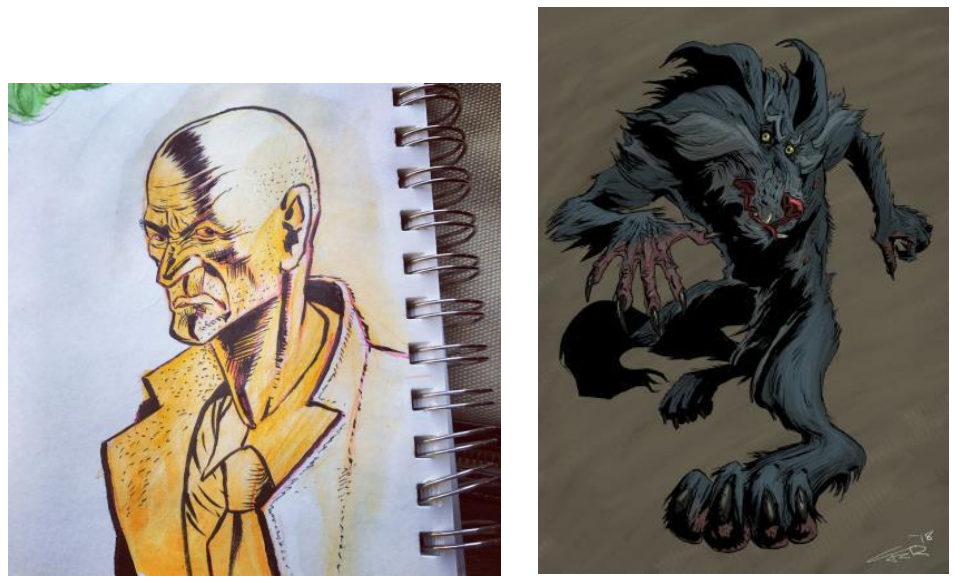

Exposure 13. Joel Rivers - paintings as an adult ${ }^{10}$

There are a number of awards for children from Bulgarian schools from our and international competitions. They impress with originality, emotional transformation, expressive

10 Paintings from Joel Rivers's website: http://www.joelrivers.com/. 
coloring, non-standard composition. In the subject of such competitions, the figure compositions are the most complex option of children's fine arts. Children from an early age paint human figures on the move, assemble sophisticated compositions, balance the composition center and supporting accessories, main and secondary characters, and expand a variety of color palettes. Plenty of our children's schools and workshops for fine arts have great achievements recognized all over the world. For examples, these are schools like "Prikazen svyat"11 in Sofia, "Kolorit"12 in Pleven, "Arteya"13 in Targovishte, etc.

Bulgarian art workshops and schools for gifted children have a rich collection of prizes from our and foreign competitions. One of the many positive examples are the children - painters from "Kolorit" School in Pleven. Three of them won a prize at the $5^{\text {th }}$ World Art Olympiad in Washington ${ }^{14}$, USA in 2015 ... Their paintings win with original composition, well-created movement, light and pure emotion ...

Here are their drawings:
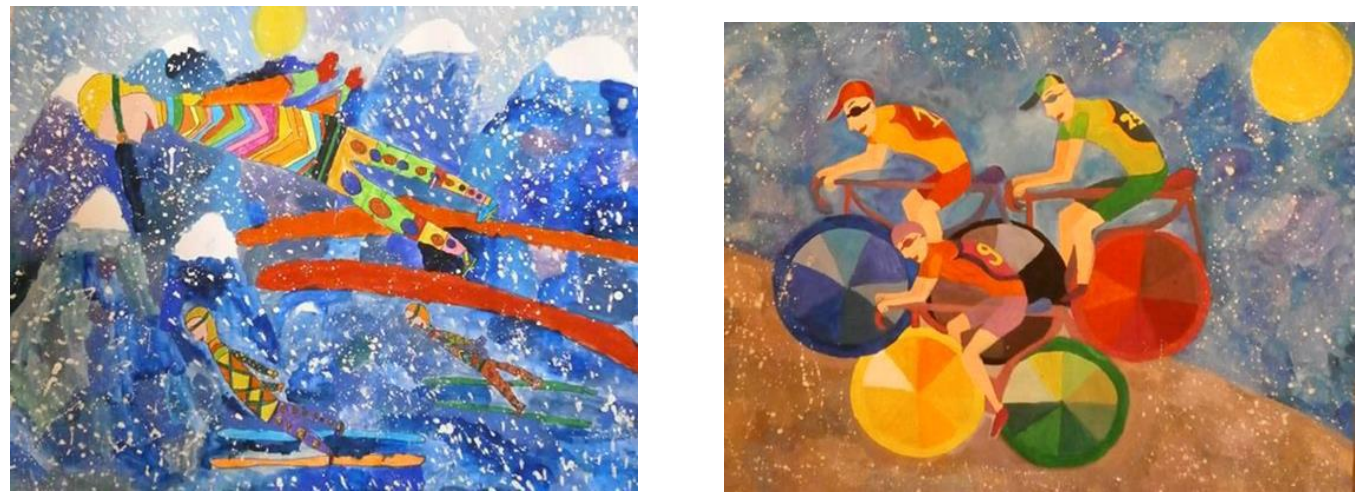

Exposure 14. Inna Chuleva - 8 years old and Kristina Gechevska - 12 years old

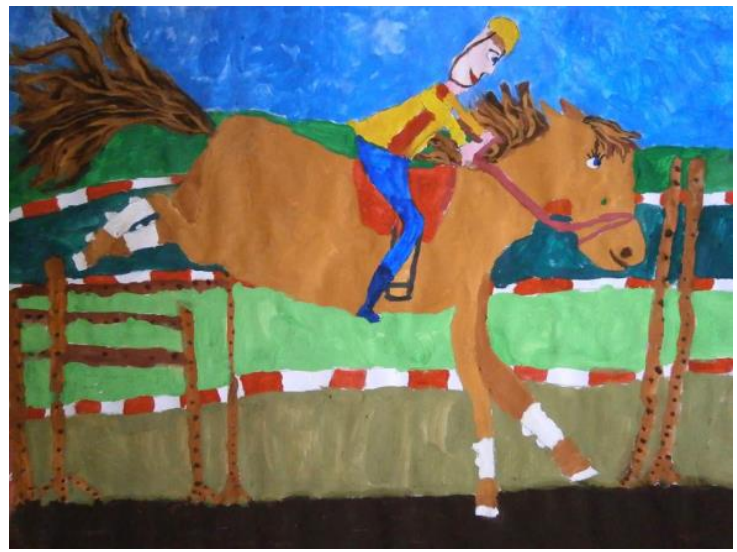

Exposure 15. Nikola Angelov - 10 years old

\footnotetext{
${ }^{11}$ http://www.prikazensviat.com/.

12 http://www.kidsarts.bg/\%Do\%Bo\%D1\%80\%D1\%82-\%D1\%88\%Do\%BA\%Do\%BE\%Do\%BB\%Do\%Bo\%Do\%BA\%Do\%BE\%Do\%BB\%Do\%BE\%D1\%80\%Do\%B8\%D1\%82-e249c45.html.

${ }^{13}$ https://arteyatg.webnode.com/.

14 Three children from "Kolorit" Art School - Pleven won the $5^{\text {th }}$ World Art Olympiad in the USA in the category "Drawing and Painting". Inna Chuleva, 8-years-old, Nikola Angelov, 10 years old, and 12-year-old Kristina Gechevska together with their art teacher Maya Ananieva will represent Bulgaria at the $5^{\text {th }}$ World Art Festival, held from 2 to 4 July 2015 in Washington.
} 
Few are the contemporary Bulgarian artists who have their own children's paintings preserved. The child's sensation, though unique, reflects in the work of the already established adult artist. To the delight of the connoisseurs of contemporary art, Doychin Russev ${ }^{15}$ is one of them. As first promises of successful creative development, as an originally declared curiosity to the world, with a pronounced attention to detail, the children's paintings by Doychin Russev are undoubtedly a good foundation and set a broad perspective for future development. And in Doychin's very first pictorial manifestations, not only on the subconscious level, we discover the discovery impetus of the innovator, the desire to travel in real and imaginary worlds ... We find a lot of movement, inner energy, narrative there - characteristics of the mature creativity of artist as well. Doychin Russev's connection with children's paintings is at the first place of the freedom of the child's consciousness, as well as in the sun's purity of color, in the constantly seeking essence of the phenomena, the transcendence of the conventions, the creation and spiritualizing of new worlds. It is obvious in "Arthur - Phantom of Sexuality" - work from 2007, participation in the project "Strategies in the Context of Childhood"16 from 2007, presented in the "Union of Bulgarian Artists" Gallery at 6, Shipka Str. In "Arthur - Phantom of Sexuality", Doychin Russev makes an ironic dissection of the contemporary heroics and its roots in childhood. The artist uses some quotations such as his photo as a child, and comics' clippings as references to relevant episodes and situations.
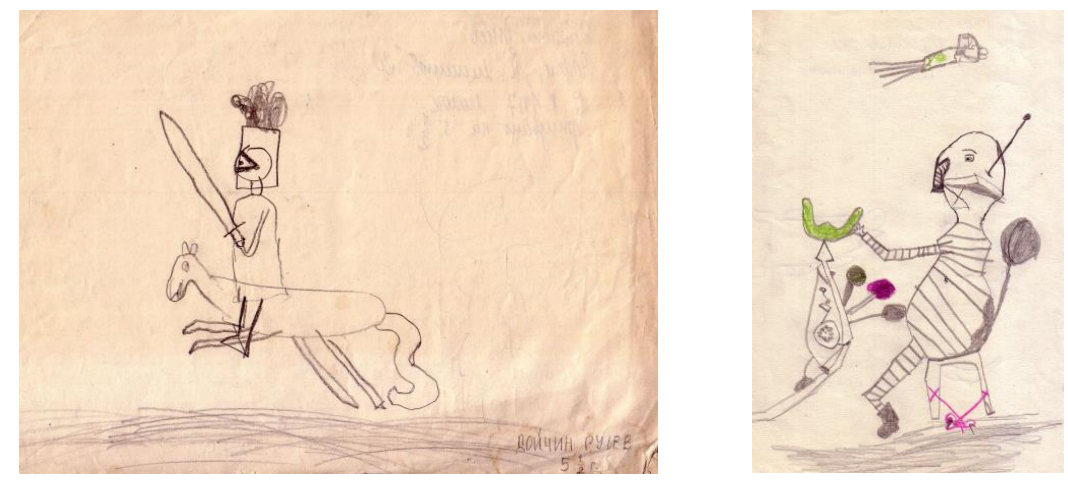

Exposure 16. Doychin - 6 years old
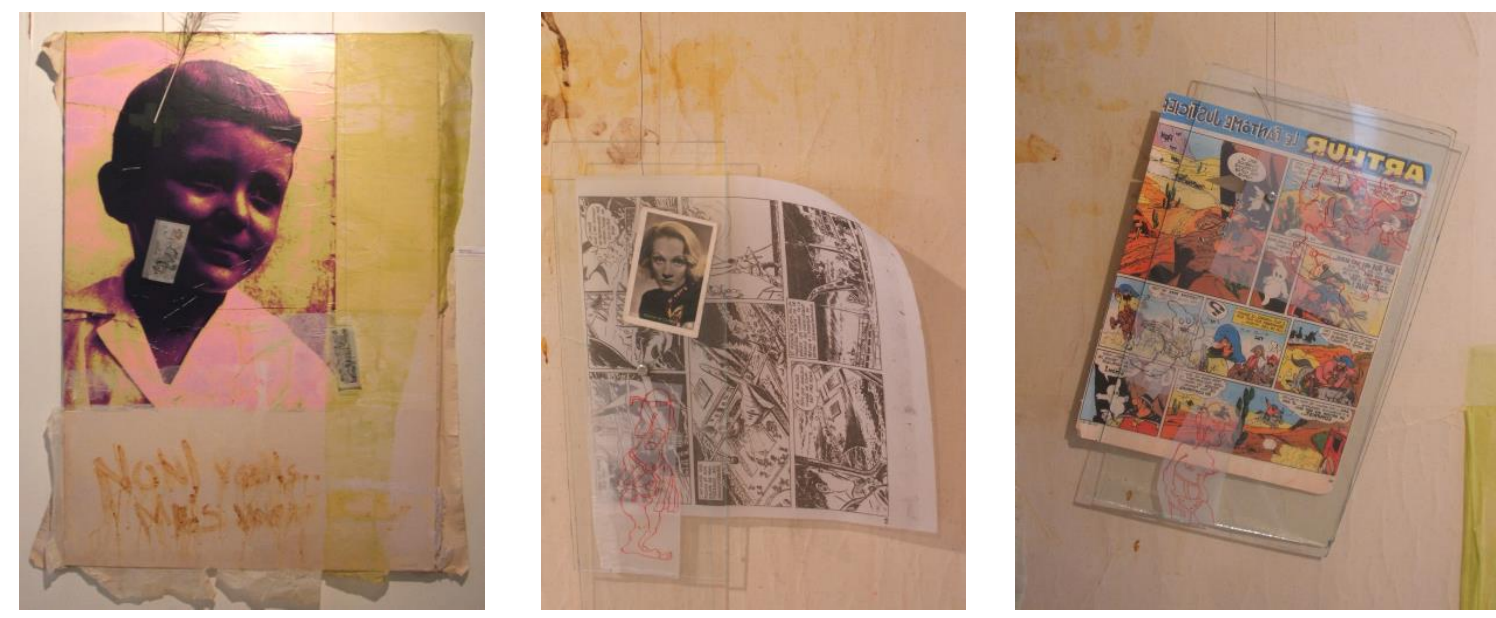

15 http://www.arosita.info/index.php?itemId=123\&lang=bg.

https://www.bacchus.bg/spisanie/2008/11/04/576401 parij na edin bulgarski bohem/.

16 "Strategies in the Context of Childhood", curatorial project of Nikolay Marinov (author) from 2007, presented in the "Union of Bulgarian Artists" Gallery at 6, Shipka Str. 
Exposure 17. Doychin Russev, "Artur-phantom of Sexuality"1, detail A, detail B

Children's art takes a particularly important place in the artistic projects of Elena Panayotova. She is interested, for example, from the mature perception of the things compared to Childhood. Evidence of this is her chronological search concerning the paintings and belongings of her childhood. Elena introduces new life to her preserved children's paintings, repainting them, quoting and turning them into pictures. In her independent exhibition, "Partial Chronology of Identity", presented in the National Art Gallery ${ }^{17}$, the painter brought to light and exhibited her forgotten things and paintings made on them.

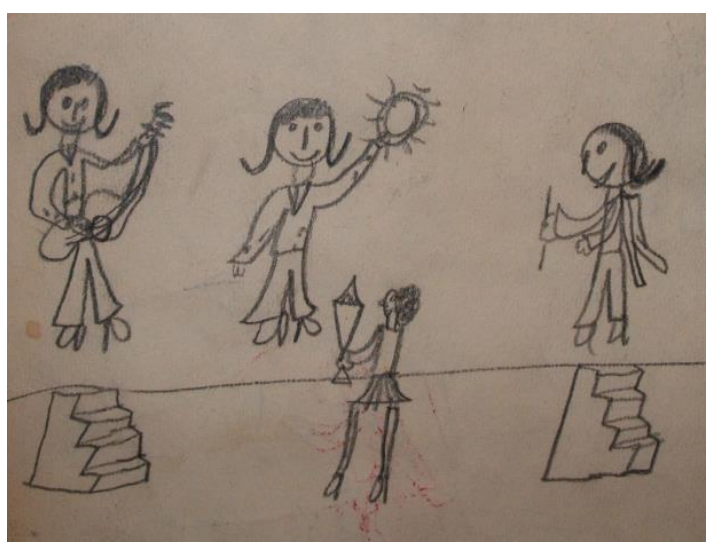

Exposure 18. Elena Panayotova - 8 years old (preserved child painting of the artist, detail)
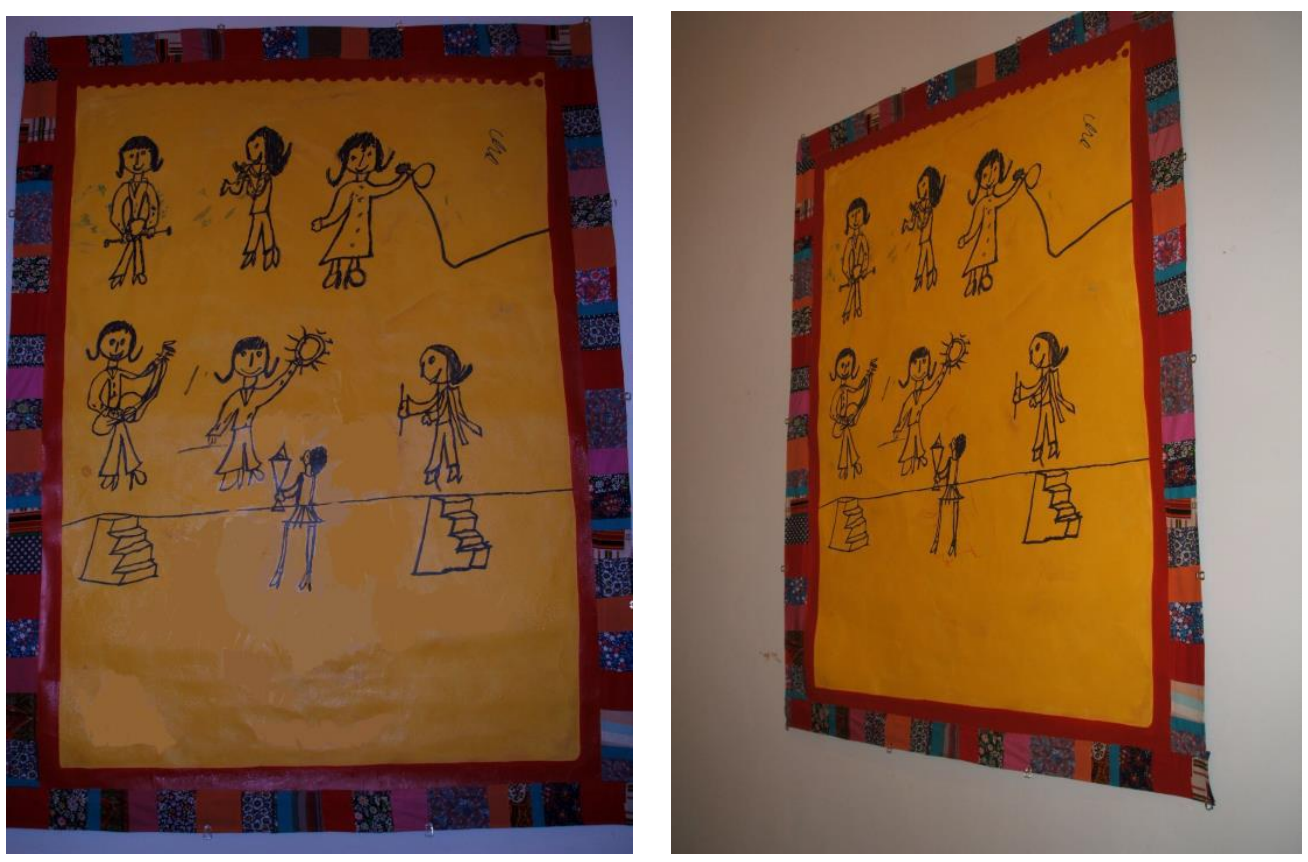

Exposure 19. Of "Partial Chronology of Identity", National Art Gallery, 2006

Preserved paintings from her childhood can be shown by the artist Monika Popova ${ }^{18}$.

\footnotetext{
${ }_{17}$ Elena Panayotova presents her exhibition "Partial Chronology of Identity" in March, 2006 in the National Art Gallery.

${ }^{18}$ http://vitoshagallery.com/bg/content/\%Do\%BC\%Do\%BE\%Do\%BD\%Do\%B8\%Do\%BA\%Do\%Bo\%Do\%BF\%Do\%BE\%Do\%BF\%Do\%BE\%Do\%B2\%Do\%Bo.
} 


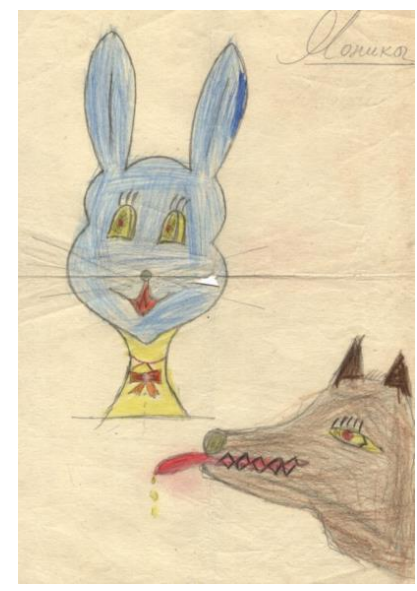

Exposure 20. Monika Popova, Children's painting

The exhibition presented by Monika Popova at the Art Aleya Gallery in Sofia "Paintings before Bedtime" 19 is interesting... According to the author herself: "The exhibition presents paintings I have created: - in the hours before I fall asleep; - at times when the fatigue was so great that I did not feel my body; - in moments when I decided to take a fine-tipped pen instead of a pill; - at times when happiness or pain I could not transform in another way; - at times when I wanted to dissolve in nowhere!”. As in previous projects, Monika Popova shows over-emotional expressiveness.
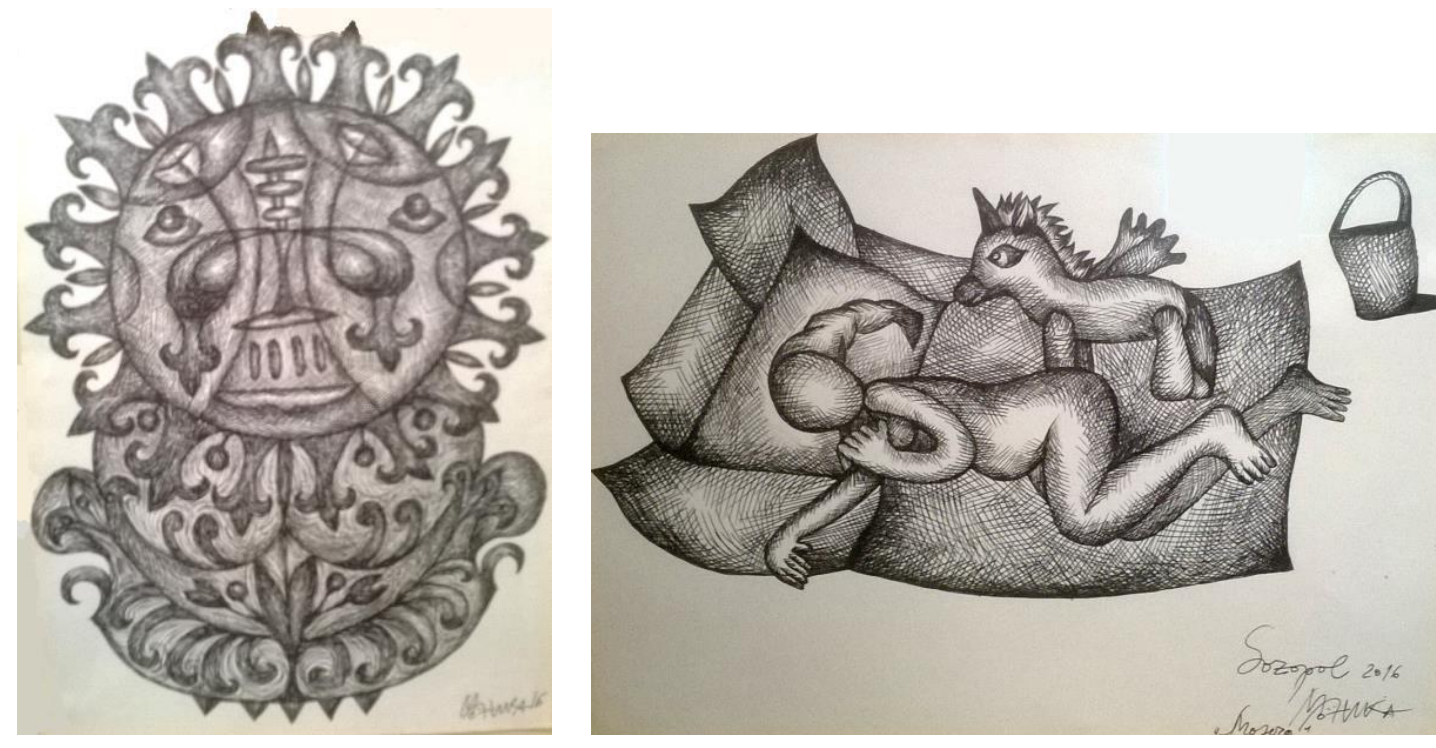

Exposure 21. Monika Popova, Gallery “Art Aleya”, Sofia, February 2019

The presented artists and works are only a very small part of the possible examples that deserve to be shown. Childhood and children's creativity definitely requires attention not only as a brief and interesting time, a source of inspiration, events, colors, but also as a special unexplored territory that invariably forms the basis and determines the life and creative path of the adult artist. The preserved children's paintings of established artists not only provoke admiration, they reveal early artistic talent but also show the correlation between childhood and

${ }^{19}$ https://sofia-art-galleries.com/event/risunki-predi-lyagane-izlozhba-na-monika-popova-v-galeriya-artaleya/. 
maturity, childhood as a fairytale, magical and unique source of inspiration, the first discoveries for the world in our unique and irreplaceable way.

\section{Acknowledgements}

This research did not receive any specific grant from funding agencies in the public commercial, or not-for-profit sectors.

The author declares no competing interests.

\section{References}

About Doychin Russev (2019). Retrieved 18 April 2019, from http://www.arosita.info/index.php?itemId=123\&lang=bg. (translation - author)

Art studio for Kids "Kolorit" - presentation. Retrieved 18 April 2019, from http://www.kidsarts.bg/\%Do\%Bo\%D1\%80\%D1\%82\%D1\%88\%Do\%BA\%D0\%BE\%Do\%BB\%Do\%Bo\%Do\%BA\%Do\%BE\%Do\%BB\%Do\%BE\%D1\% 80\%Do\%B8\%D1\%82-e249c45.html. (translation - author)

Arteya - art studio for children (2019). About us. Retrieved 18 April 2019, from: https://arteyatg.webnode.com/ (translation - author)

Children art studio "Prikazen svjat" (2019). Chronicles. Retrieved 18 April 2019, from http://www.prikazensviat.com/ (translation - author)

"Drawing before bed" (2019). Monika Popova in Gallery Art Aleya, Sofia. Retrieved 18 April 2019, from https://sofia-art-galleries.com/event/risunki-predi-lyagane-izlozhba-na-monika-popova-vgaleriya-art-aleya/. (translation - author)

Gallery Vitosha (2019). About Monika Popova. Retrieved 18 April 2019, from http://vitoshagallery.com/bg/content/\%Do\%BC\%Do\%BE\%Do\%BD\%Do\%B8\%Do\%BA\%Do \%Bo-\%Do\%BF\%Do\%BE\%Do\%BF\%Do\%BE\%Do\%B2\%Do\%Bo. (translation - author)

Golomb, C. (1995). Eitan: Artistic Development of Child Prodigy. In: C. Golomb (Ed.), The Development of Artistically Gifted Children (selected case studies) (pp. 171-196). USA: Hillsdale, New Jersey, Lawrence Erlbaum Associates Publishers.

Henri de Toulouse-Lautrec - Gallery (2019). Retrieved 18 April 2019, from https://www.toulouse-lautrecfoundation.org/.

The Human Early Learning Partnership (2019). University of British Columbia (UBC), Connie Milbrath. Retrieved 18 April 2019, from: http://earlylearning.ubc.ca/people/Connie Milbrath/.

Joan Miro famous works (2019). Wiki art encyclopedia. Retrieved 18 April 2019, from https://www.wikiart.org/en/joan-miro.

Joel Zain Rivers (2019). Visual story teller, Who I am, Illustration. Retrieved 18 April 2019, from http://www.joelrivers.com/.

Milbrath, C. (1995). Germinal Motifs in the Work of a Gifted Artist. In: C. Golomb (Ed.), The Development of Artistically Gifted Children (selected case studies) (pp.107-132). USA: Hillsdale, New Jersey, Lawrence Erlbaum Associates Publishers.

Pablo Ruiz Picasso (2019). Art periods - All works by year - 1890. Retrieved 18 April 2019, from https://www.pablo-ruiz-picasso.net/. 
Paul Klee (2019). Paintings, Biography and Quotes, Gallery. Retrieved 18 April 2019, from https://www.paulklee.net/.

Shkodrova, Albena (2008). Paris - city of one Bulgarian bohemian. Retrieved 18 April 2019, from https://www.bacchus.bg/spisanie/2008/11/04/576401_parij_na edin_bulgarski_bohem/. (translation - author)

Society for Research in Child Development (SRCD) (2019). CLAIRE GOLOMB - Professor of Psychology, University of Massachusetts/Boston - C.V. Retrieved 18 April 2019 from https://srcd.org/sites/default/files/documents/golomb claire cv.pdf. 
N. M. Dinev - Artistic Achievements of Artistically Gifted Children: Artefacts of...

C O A $\mathrm{s}$ 